\title{
Residual effects of superficial liming on tropical soil under no-tillage system
}

\author{
Claudio Hideo Martins da Costa(1), Carlos Alexandre Costa Crusciol(2), \\ Jayme Ferrari Neto(2) e Gustavo Spadotti Amaral Castro ${ }^{(3)}$
}

(1)Universidade Federal de Goiás, Regional Jataí, Campus Cidade Universitária, BR 364, km 195, no 3.800, CEP 75801-615 Jataí, GO, Brazil.
E-mail: c_hideo@hotmail.com (2)Universidade Estadual Paulista, Faculdade de Ciências Agronômicas, Campus de Botucatu, Caixa Postal
237, CEP 18603-970 Botucatu, SP, Brazil. E-mail: crusciol@fca.unesp.br, jfneto@fca.unesp.br (3)Embrapa Monitoramento por Satélite,
Avenida Soldado Passarinho, no 303, Fazenda Jardim Chapadão CEP 13070-115 Campinas, SP, Brazil. E-mail: gustavo.castro@embrapa.br

Abstract - The objective of this work was to evaluate the long-term effects of the surface application of lime on soil fertility and on the mineral nutrition and grain yield of soybean, and of black oat and sorghum in crop succession. The experiment was carried out on a clayey Oxisol, in a randomized complete block design, with four replicates. Treatments consisted of lime the rates of $0,1,000,2,000$, and 4,000 $\mathrm{kg} \mathrm{ha}^{-1}$, applied in October 2002 and November 2004. Soil samples were collected at five soil layers, down to $0.60-\mathrm{m}$ depth. Surface liming was effective in reducing soil acidity and increasing $\mathrm{Ca}^{2+}$ and $\mathrm{Mg}^{2+}$ contents in the subsurface. Moreover, it increased available phosphorus contents and soil organic matter in the long term (48 to 60 months after the last lime application). Surface liming improved plant nutrition, mainly for $\mathrm{N}, \mathrm{Ca}$, and $\mathrm{Mg}$, and increased dry matter production and grain yield of the crops, even in years with regular distribution of rainfall. The greatest productivities of soybean, black oat, and sorghum were obtained with the respective estimated lime doses of $4,000,2,333$, and 3,281 $\mathrm{kg} \mathrm{ha}^{-1}$, for shoot dry matter, and of 2,550,3,555, and over 4,000 kg ha-1, for grain yield.

Index terms: crop rotation, long-term experiment, plant nutrition, soil fertility, subsurface soil acidity, yield components.

\section{Efeitos residuais da calagem superficial em solo tropical com plantio direto}

Resumo - O objetivo deste trabalho foi avaliar os efeitos em longo prazo da aplicação superficial de calcário sobre a fertilidade do solo e sobre a nutrição mineral e a produtividade de soja, e de aveia-preta e sorgo em sucessão. O experimento foi realizado em Latossolo Vermelho argiloso, em delineamento de blocos ao acaso, com quatro repetições. Os tratamentos consistiram das doses de calcário de: $0,1.000,2.000$ e $4.000 \mathrm{~kg} \mathrm{ha}^{-1}$, aplicadas em outubro de 2002 e novembro de 2004. Amostras de solos foram tiradas de cinco camadas do solo, até a profundidade de $0,60 \mathrm{~m}$. A calagem superficial foi efetiva em reduzir a acidez do solo e elevar os teores de $\mathrm{Ca}^{+2} \mathrm{e} \mathrm{Mg}^{+2}$ em profundidade. Além disso, ela elevou os teores de fósforo disponível e de matéria orgânica do solo, em longo prazo (48 a 60 meses após a última calagem). A calagem superficial melhorou a nutrição das plantas, principalmente quanto a $\mathrm{N}, \mathrm{Ca}$ e $\mathrm{Mg}$, e aumentou a produção de matéria seca e a produtividade de grãos da culturas, mesmo em anos com distribuição regular de chuvas. As maiores produtividades de soja, aveia-preta e sorgo foram obtidas com as respectivas doses de calcário estimadas em 4.000, 2.333 e 3.281 $\mathrm{kg} \mathrm{ha}^{-1}$, para a matéria seca da parte aérea, e de $2.550,3.555$ e mais de $4.000 \mathrm{~kg} \mathrm{ha}^{-1}$, para a produção de grãos.

Termos para indexação: rotação de culturas, experimentos de longa duração, nutrição de plantas, fertilidade do solo, acidez subsuperficial do solo, componentes da produção.

\section{Introduction}

Sustainable agricultural systems should avoid leaving the fields unplanted and the soils exposed, during the autumn-winter period, in the Brazilian Southeast Region agricultural off-season. In this period, the irregular distribution of rain and low rainfalls are the main factors that affect shoot dry matter production and yield of annual crops. Thus, studies of techniques and crops that are well suited to these conditions are important to enable cultivation during water-deficit periods (Soratto \& Crusciol, 2008c, 2008d).

Soybean [Glycine max (L.) Merrill] is one of the most widespread summer crops in the Brazilian Cerrado region. Because of its great economic importance, this crop has been successively cultivated even more often, causing crop rotation schemes to become overly 
simplified. Black oat (Avena strigosa Schreber) and sorghum (Sorghum bicolor) are attractive succession crops for soybean, due to their relative tolerance to limited water availability.

Low $\mathrm{pH}$ values and low base saturation levels in tropical soils can affect root growth and water and nutrient uptake, especially in dry winter regions. Superficial liming is commonly used to reduce soil acidity in no-till (NT). This technique rapidly reduces the acidity on soil surface, but its effects at deeper layers are slow, particularly in soils with variable charges (Ernani et al., 2004). Lime movement through the soil varies with soil type and structure, intrinsic characteristics of the product, climatic conditions, acid fertilizer management, and crop systems (Ernani et al., 2004; Caires et al., 2005).

In subtropical regions of Brazil, where rainfall is well distributed throughout the year, there are several reports of a lack crop response to the lime application in no-till systems (Caires et al., 2006b, 2008a, 2008b, 2011). These findings have been attributed to a greater accumulation of organic matter and nutrients on the soil surface, which reduces the activity of Al by forming Al-organic complexes, and by increasing ionic strength of soil solution (Nolla \& Anghinoni, 2006; Vieira et al., 2009). However, in the majority of the Cerrado biome, in Brazil, mainly in the areas with dry winter, increases of grain yield and fiber production are expected with lime application in no-till systems, even if it is done on the soil surface, unlike what has been observed elsewhere in the subtropical region. This possibility exists because, in these regions, the majority of cultivated areas have a low organic matter content and low amount of crop residues left on the soil surface, leading, respectively, to low water storage and high evaporation.

Superficial application of correctives can reduce soil acidity and improve nutrient availability (Caires et al., 2005; Soratto \& Crusciol, 2008a, 2008b, 2008c, 2008d), which is reflected in increased biomass production, nutrient accumulation, and grain yield (Castro \& Crusciol, 2013a), even in crops considered tolerant to water stress, such as black oat and sorghum. However, it should be emphasized that few studies have investigated the long-term effects (more than nine years) of superficial limestone application on soil chemical properties, and the response of black oat and sorghum in a tropical NT system with dry winter.
The objective of this work was to evaluate the longterm effects of the surface application of lime on soil fertility and on the mineral nutrition and grain yield of soybean, and of black oat and sorghum in crop succession.

\section{Materials and Methods}

The experiment was carried out at Lageado Experimental Farm, of the Universidade Estadual Paulista, in Botucatu, SP, Brazil (48 $23^{\prime} \mathrm{W}, 22^{\circ} 51^{\prime} \mathrm{S}$, at $765 \mathrm{~m}$ altitude). The soil in the area is a deep, acidic, clayey Oxisol. The climate is Cwa - tropical, with a dry winter and hot, rainy summer -, according to the classification ofKöppen-Geiger.During the experiment, monthly averages for rainfall and temperatures were, in December 2008, $137 \mathrm{~mm}$ and $22.7^{\circ} \mathrm{C}$, respectively; and in 2009, they were, respectively, as follows: 263 $\mathrm{mm}$ and $22.6^{\circ} \mathrm{C}$, in January; $97 \mathrm{~mm}$ and $23.4^{\circ} \mathrm{C}$, in February; $60 \mathrm{~mm}$ and $22.9^{\circ} \mathrm{C}$, in March; $161 \mathrm{~mm}$ and $21.2^{\circ} \mathrm{C}$, in April; $70 \mathrm{~mm}$ and $18.3^{\circ} \mathrm{C}$, in May; $16 \mathrm{~mm}$ and $17.9^{\circ} \mathrm{C}$, in June; $3 \mathrm{~mm}$ and $19.2^{\circ} \mathrm{C}$, in July; 101 $\mathrm{mm}$ and $20.3^{\circ} \mathrm{C}$, in August; $75 \mathrm{~mm}$ and $20.4^{\circ} \mathrm{C}$, in September; $118 \mathrm{~mm}$ and $22.3^{\circ} \mathrm{C}$, in October; $59 \mathrm{~mm}$ and $22.3^{\circ} \mathrm{C}$, in November; $343 \mathrm{~mm}$ and $22.5^{\circ} \mathrm{C}$, in December; and 2010: $180 \mathrm{~mm}$ and $22.5^{\circ} \mathrm{C}$, in January; and $108 \mathrm{~mm}$ and $23.5^{\circ} \mathrm{C}$, in February .

The research has been conducted since 2002, maintaining the same treatments of lime in an NT crop rotation. In 2002/2003, 2003/2004, 2004/2005, 2005/2006, 2006/2007, 2007/2008, 2008/2009, and $2009 / 2010$, the following main and second crops were respectively grown: rice/oat, common bean/ oat, peanut/oat, peanut/oat, corn intercropped with Urochloa grass, corn intercropped with Urochloa grass, soybean/black oat, and soybean/grain sorghum.

Topsoil $(0.0-0.2 \mathrm{~m})$ chemical characteristics were determined (Table 1) at the beginning of the experiment (October 2002), and before the last lime application (August 2004). On October 15, 2002, lime treatments were applied superficially. The last application was on November 19, 2004, based on the soil analysis carried out in August 2004.

A randomized complete block design was carried out with four replicates. The plot dimensions were $5.4 \times 9.0 \mathrm{~m}$. The treatments consisted of following four lime rates: necessary dose to raise the base saturation to $70 \%$, which is the recommended rate $\left(2,000 \mathrm{~kg} \mathrm{ha}^{-1}\right)$, 
according to Raij et al. (1997); half of the recommended rate $\left(1,000 \mathrm{~kg} \mathrm{ha}^{-1}\right)$; double of the recommended rate $\left(4,000 \mathrm{~kg} \mathrm{ha}^{-1}\right)$; and a control without liming. Dolomitic limestone was applied with the following composition: $23.3 \% \mathrm{CaO}, 17.5 \% \mathrm{MgO}$, and $71 \%$ effective calcium carbonate equivalence (ECCE). In the physical analysis of the dolomitic limestone, 68.8, 92.4, and $99.7 \%$ of particles passed 50, 20, and 10 mesh sieves, respectively.

Soybean [Glycine $\max$ (L.) Merrill] was sown on December 11, 2008, and on October 29, 2009, using the cultivars MG/BR 46 Conquista and CD 216, respectively. The row spacing used was $0.45 \mathrm{~m}$, and the seed rates were approximately 22 seeds $\mathrm{m}^{-1}$. The base fertilization consisted of $250 \mathrm{~kg} \mathrm{ha}^{-1}$ of $04-20-20$ $\mathrm{N}-\mathrm{P}_{2} \mathrm{O}_{5}-\mathrm{K}_{2} \mathrm{O}$ formula, according to the results of soil chemical analysis and soybean crop recommendations (Raij et al., 1997). Harvesting was performed on April 24, 2009, and on February 24, 2010. Samples were taken for determining yield components (plant population, number of pods per plant, number of grains per pod, and 100-grain weight) and final yield (130 $\mathrm{g} \mathrm{kg}^{-1}$ moisture content).

Black oat (Avena strigosa Schreb.) and sorghum [Sorghum bicolor (L.) Moench] were sown on June 22, 2009, and on March 08, 2010, using the variety "comum" and the hybrid AG 1020, respectively. The row spacings were $0.17 \mathrm{~m}$ and $0.60 \mathrm{~m}$, with seed rates at $60 \mathrm{~kg} \mathrm{ha}^{-1}$ and 18 seeds $\mathrm{m}^{-1}$, respectively. Black oat and sorghum were harvested on October 19, 2009, and July 21, 2010, respectively. Samples were taken for determining yield components as follows: for both black oat and sorghum, grain yield (130 $\mathrm{g} \mathrm{kg}^{-1}$ moisture content); for black oat, panicles per square meter, spikelets per panicle, and 1,000-grain weight;

Table 1. Soil chemical characteristics before the experiment (October 2002), and before the last lime application (August 2004).

\begin{tabular}{lcccccccccc}
\hline $\begin{array}{l}\text { Soil } \\
\text { depth } \\
(\mathrm{m})\end{array}$ & $\begin{array}{c}\mathrm{pH} \\
\mathrm{CaCl}_{2}\end{array}$ & SOM & $\mathrm{P}_{\text {resin }}$ & $\mathrm{H}+\mathrm{Al}$ & $\mathrm{Al}$ & $\mathrm{K}$ & $\mathrm{Ca}$ & $\mathrm{Mg}$ & $\mathrm{CEC}$ & $\begin{array}{c}\mathrm{BS} \\
(\%)\end{array}$ \\
\hline \multicolumn{8}{c}{ October 2002} \\
$0.0-0.2$ & 4.2 & 21 & 9 & 37 & 6.5 & 1.2 & 14 & 5 & 58 & 37 \\
\hline \multicolumn{8}{c}{ August 2004} \\
$0.0-0.2$ & 4.9 & 27 & 35 & 35 & 2.3 & 1.1 & 24 & 10 & 70 & 50 \\
\hline
\end{tabular}

and for sorghum, panicles per square meter, grains per panicle, 1,000-grain weight.

Soil samples were collected after 48 and 60 months from lime reapplication (August 2004), at 0.0-0.05, $0.05-0.10,0.10-0.20,0.20-0.40$, and $0.40-0.60 \mathrm{~m}$ soil depths. Seven subsamples were taken randomly from each plot, between the rows, and combined into one composite sample. Soil $\mathrm{pH}$ was determined in a $0.01 \mathrm{~mol} \mathrm{~L}^{-1} \mathrm{CaCl}_{2}$ suspension (1:2.5 soil/solution). Total acidity in $\mathrm{pH} 7.0(\mathrm{H}+\mathrm{Al})$ was estimated with the SMP-buffer solution method (Raij et al., 1997). Exchangeable Al was extracted with neutral $1 \mathrm{~mol} \mathrm{~L}^{-1}$ $\mathrm{KCl}$ at a 1:10 soil/solution ratio, and determined by titration with $0.025 \mathrm{~mol} \mathrm{~L}^{-1} \mathrm{NaOH}$ solution. Phosphorus and exchangeable $\mathrm{Ca}$ and $\mathrm{Mg}$ were extracted with ionexchange resin, and determined by atomic absorption spectrophotometry. Base saturation values were calculated using the results of exchangeable bases and total acidity at $\mathrm{pH} 7.0(\mathrm{H}+\mathrm{Al})$ (Raij et al., 1997).

Growing season means (only for soybean plant results) were compared using Fisher's protected LSD test at $5 \%$ probability. The dolomitic limestone rates were analysed using regression analysis, testing regression coefficients significant at $5 \%$ probability with the t-test.

\section{Results and Discussion}

The sampling carried out 48 months after the last surface liming exhibited linear increase of soil $\mathrm{pH}$, and reduction of potential acidity $(\mathrm{H}+\mathrm{Al})$, at all depths. These effects were also observed after 60 months, but only up to 0.40 and $0.20 \mathrm{~m}$ soil depths, respectively (Figure 1). Lower $\mathrm{pH}$ values were observed in the latter sampling, compared to the previous one. Reductions of $\mathrm{Al}^{3+}$ levels were observed up to $0.20 \mathrm{~m}$ soil depth, at both samplings.

Those last reductions can be partly explained by the fact that the area was maintained in an NT system since 2002, and by the higher soil organic matter contents (Figure 1) and $\mathrm{Ca}^{2+}$ concentration (Figure 2) derived from lime which may have acted in the formation of complexes of $\mathrm{Al}^{3+}$ with clay and organic matter through the cation bridge (Bronick \& Lal, 2005). These complexes also contribute to the improvement of soil aggregation and aggregate stability (Briedis et al., 2012). Moreover, low disturbance in NT also favors the maintenance or formation of channels by biological 

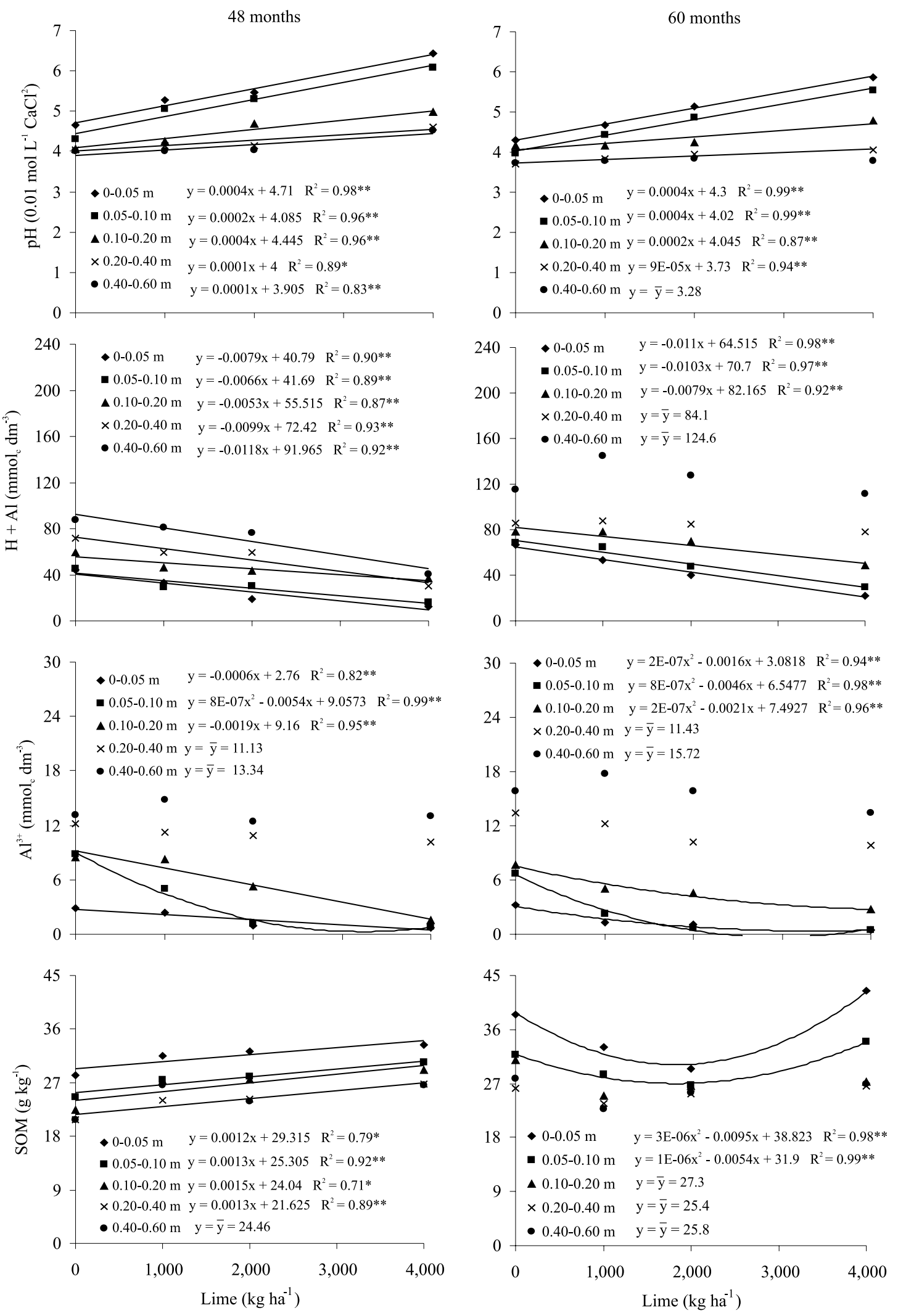

Figure 1. Effects of superficial liming on $\mathrm{pH}$, soil organic matter $(\mathrm{SOM}), \mathrm{H}+\mathrm{Al}$, and $\mathrm{Al}^{3+}$, after 48 and 60 months from the last lime application, at different soil depths. *, **Significant at 1 and $5 \%$ probability, respectively. 

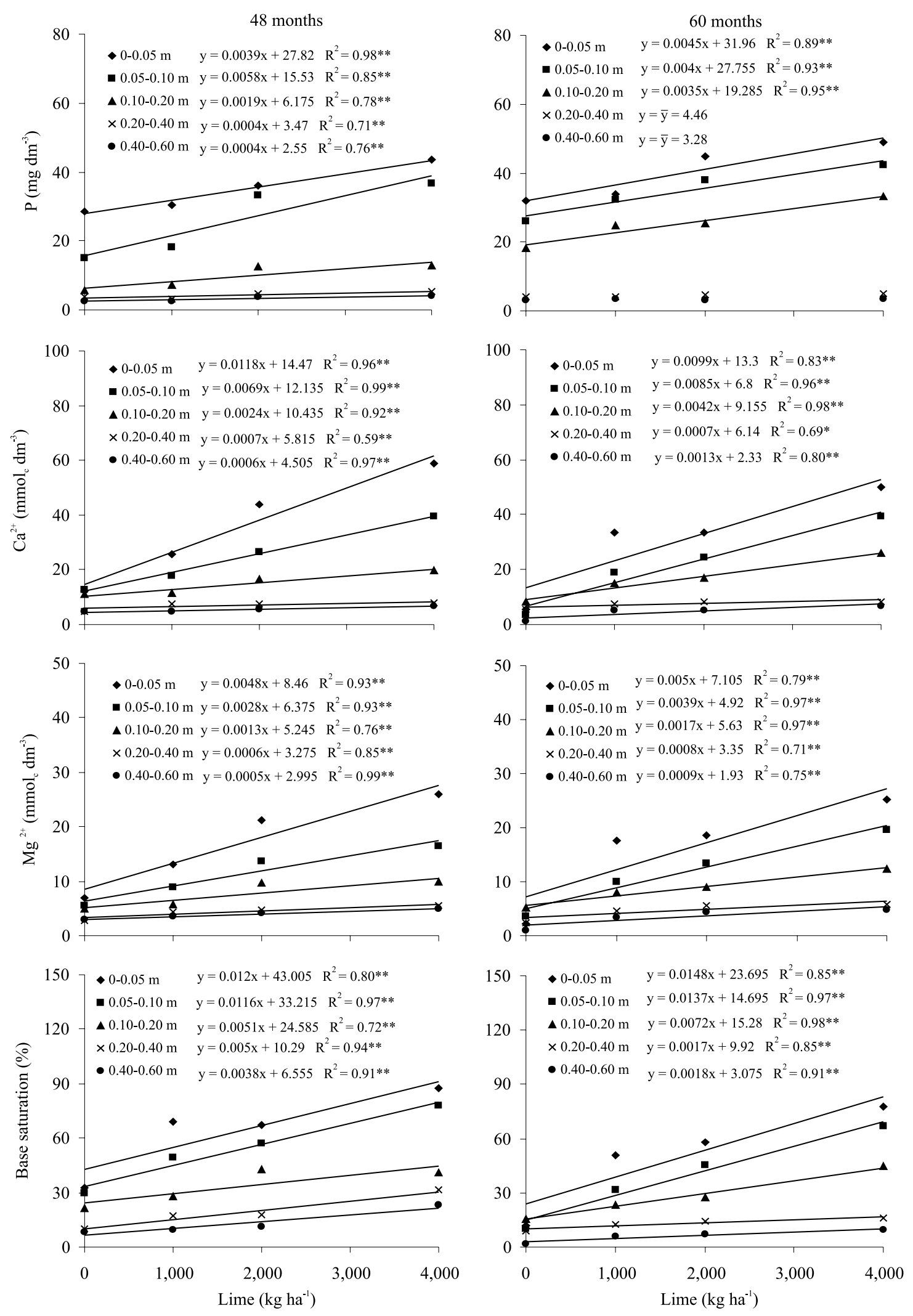

Figure 2. Effects of superficial liming on the availability of $\mathrm{P}, \mathrm{Ca}$, and $\mathrm{Mg}$ in the soil, and on base saturation, after 48 and 60 months from the last lime application, at different soil depths. *,**Significant at 1 and $5 \%$ probability, respectively. 
activity, which is considered an important route for the physical movement of corrective particles along with downward water movement, which makes the carbonate reaction possible at higher depths (Corrêa et al., 2009).

The $\mathrm{pH}$ increase on soil surface due to superficial liming can accelerate the rate at which $\mathrm{HCO}_{3}{ }^{-}$ions, followed by $\mathrm{Ca}^{2+}$ and $\mathrm{Mg}^{2+}$, move into the subsoil to react with acidity, an effect known as an "alkalizing front" (Caires et al., 2005, 2008b, 2008c, 2011; Soratto $\&$ Crusciol, 2008a). In addition, the high amount of plant residues left on soil surface in no-till systems can mobilize cations and increase the mobility of surfaceapplied lime, due to the release of low molecularweight organic acids from the soluble fraction of residues (Pavan \& Roth, 1992; Oliveira \& Pavan, 1996; Miyazawa et al., 2002; Franchini et al., 2003). In this context, the Ca-fulvate complex stands out, since it is very stable and $\mathrm{Ca}^{2+}$ release occurs very slowly while the complex is transported downwards into the soil profile (Watt et al., 1991). Irrespective of the mechanism involved, it is evident that the already established surface liming in NT is effective to reduce the soil acidity in depth.

Soil acidity increased over time, which can be attributed to the maximum limestone reaction within 48 months (Figure 1). Ciotta et al. (2002) also reported soil acidification in NT system, and related this result to ammonium nitrification process from fertilizers. Several studies have shown that the maximum duration time of liming on soil surface is variable, with representative values including 48 months, in a dystrophic Ultisol with medium texture (Rheinheimer et al., 2000), and 18 months in a clayey Oxisol (Soratto \& Crusciol, 2008a, 2008b).

At 48 months after liming, soil organic matter levels increased linearly up to $0.40 \mathrm{~m}$ soil depth (Figure 1), which is related to the increased dry matter production of shoots and roots of the preceding crop (maize). After 60 months, this effect was limited to $0.10 \mathrm{~m}$ (Figure 1), which corresponds to lower dry matter production of shoots and roots by soybean and black oat. A clear accumulation of soil organic matter occurs in the long run. However, it is dependent on the plant species used in the crop rotation; therefore, the use of plants with different root systems and inputs of shoot dry matter should be prioritized.
Liming caused linear increase of $\mathrm{P}, \mathrm{Ca}^{2+}$, and $\mathrm{Mg}^{2+}$ levels at all depths, after 48 months; most of these were significant up to $0.20 \mathrm{~m}$ soil depth (Figure 2). After 60 months, similar effects of liming were observed, but $P$ level trend was restricted to $0.20 \mathrm{~m}$ depth. Greater $\mathrm{P}$ levels can be attributed to the reduced $\mathrm{P}$ adsorption, due to the increasing soil $\mathrm{pH}$ (Figure 1), and to the following increased solubility of iron and aluminium phosphates (Souza et al., 2006). Thus, the annual $\mathrm{P}$ addition by fertilization increases $\mathrm{P}$ availability, as lime reduces the force with which the element is retained in the soil. Similar results were observed by Castro \& Crusciol (2013a).

$\mathrm{Ca}^{2+}$ and $\mathrm{Mg}^{2+}$ increased proportionally to the applied dose (Figure 2), as lime is a source of these nutrients. Several authors reported an increase of the exchangeable $\mathrm{Ca}^{2+}$ in the soil from lime surface application (Caires et al., 2005, 2006b, 2006c, 2006d, 2008a, 2008b, 2008c; Soratto \& Crusciol, 2008a). It is noteworthy that the increase of these nutrients in the subsurface layers may be related to the formation of inorganic ion pairs with $\mathrm{NO}_{3}^{-}, \mathrm{HCO}_{3}^{-}, \mathrm{OH}^{-}$ (Rheinheimer et al., 2000), $\mathrm{Cl}^{-}$, and $\mathrm{SO}_{4}^{-2}$ (Caires et al., 2006a) from mineral fertilizers or plant residues.

There was a slight decrease of $\mathrm{Ca}^{2+}$ and $\mathrm{Mg}^{2+}$ levels over time, similarly to what was observed in $\mathrm{pH}$ values (Figure 1). These reductions can be attributed to the extraction of the elements by previous crops. Soratto \& Crusciol (2008a) also observed a reduction in the exchangeable $\mathrm{Ca}^{2+}$ levels over time following superficial liming, especially in the surface layers.

Base saturation increased linearly with lime doses throughout the soil profile (Figure 2). This effect in the subsurface shows the technical viability of this practice in cultivated tropical soils under NT.

There was no significant interaction between treatments and years, for none of the nutrients evaluated on soybean leaves (Table 2). Concentrations of $\mathrm{P}$ and Fe were not influenced by liming; and concentrations of $\mathrm{N}$, or $\mathrm{Zn}^{2+}$, or $\mathrm{Mn}^{3+}$ were not influenced by year. The highest $\mathrm{P}, \mathrm{K}^{+}, \mathrm{Ca}^{2+}, \mathrm{Mg}^{2+}, \mathrm{S}, \mathrm{Cu}^{2+}$, and $\mathrm{Fe}^{3+}$ concentrations were observed in 2008/2009 (Table 2), which is in accordance with the high nutrient levels in the previous soil sampling (48 months).

Nitrogen concentrations, increased by liming in soybean and sorghum leaves (Table 3), showed their beneficial effects of this practice on symbiotic $\mathrm{N}_{2}$ fixation process and on soil nitrate availability. The 
symbiotic efficiency of $\mathrm{N}_{2}$ fixation is associated with the higher availability of Mo and less $\mathrm{Mn}^{3+}$, due to the reduction of soil acidity, which can also increase nitrate availability, since the nitrification activity can increase up to 5-fold with increasing $\mathrm{pH}$ values (Islam et al., 2006).

No effects of lime were observed on nutrient levels in oat leaves, which was also reported by other authors for white oat (Castro \& Crusciol, 2013a) and black oat (Soratto \& Crusciol, 2008d).

Superficial liming positively influenced $\mathrm{Ca}^{2+}$ and $\mathrm{Mg}^{2+}$ uptake, as observed for soybean, sorghum, and black oat, in established NT systems (Table 3). These results corroborate those obtained by Castro \& Crusciol (2013a, 2013b) for several crops. These results had a direct effect on potassium uptake by soybean and sorghum, which shows an antagonist effect between the nutrients, as they compete for the same uptake sites. Similar results were observed by Caires et al. (2002) in corn, but without consequence for grain yield.

Liming increased $\mathrm{P}$ uptake by sorghum (Table 3), and this agrees with the increased levels of $\mathrm{P}$ in the soil after the correction of soil acidity (Figure 2). The greater uptake of $\mathrm{S}$ by soybean and sorghum after liming may be a consequence of adsorbed sulphate release due to the increase of the topsoil $\mathrm{pH}$ (Caires et al., 1999), or to the greater mineralization of organic $\mathrm{S}$.

Micronutrient concentrations in the leaves of soybean $\left(\mathrm{Cu}^{2+}, \mathrm{Zn}^{2+}\right.$ and $\left.\mathrm{Mn}^{3+}\right)$, black oat $\left(\mathrm{Mn}^{3+}\right.$ and $\left.\mathrm{Fe}^{3+}\right)$, and sorghum $\left(\mathrm{Mn}^{3+}\right)$ were also reduced with liming (Table 3). The $\mathrm{pH}$ increase after liming especially reduces the availability of cationic micronutrients in the soil (Malavolta et al., 1997). Sávio et al. (2011) also reported reductions of $\mathrm{Zn}^{2+}$ and $\mathrm{Mn}^{3+}$ contents in soybean leaves, under NT with increased soil $\mathrm{pH}$.

There was no significant interaction between the factors for soybean yield components (Table 2). In 2008/2009, shoot dry matter yield, plant population, and 100-seed weight were higher than in 2009/2010; however, in 2009/2010, a higher number of grains per pod resulted in higher grain yield. Soybean yield was higher in 2009/2010, due to the larger number of grains per pod, which is a characteristic of the selected cultivar (CD 216).

Table 2. Nutrient content in leaves, shoot dry matter yield, yield components, and grain yield of soybean, black oat, and sorghum, followed by the significance values of the $\mathrm{F}$ test from the analysis of variance.

\begin{tabular}{|c|c|c|c|c|c|c|c|c|c|c|c|c|c|c|c|c|}
\hline \multirow[t]{2}{*}{ Factor } & $\mathrm{N}$ & $\mathrm{P}$ & $\mathrm{K}$ & $\mathrm{Ca}$ & $\mathrm{Mg}$ & \multirow[t]{2}{*}{ S } & $\mathrm{Cu}$ & $\mathrm{Zn}$ & $\mathrm{Mn}$ & \multirow{2}{*}{$\mathrm{Fe}$} & \multirow{2}{*}{$\begin{array}{c}\text { Shoot DM } \\
\left(\mathrm{kg} \mathrm{ha}^{-1}\right)\end{array}$} & \multicolumn{3}{|c|}{ Yield Component } & \multirow{2}{*}{$\begin{array}{l}\text { 100-grain } \\
\text { weight }(\mathrm{g})\end{array}$} & \multirow{2}{*}{$\begin{array}{c}\text { Grain yield } \\
\left(\mathrm{kg} \mathrm{ha}^{-1}\right)\end{array}$} \\
\hline & ------- & -------- & $-\left(\mathrm{g} \mathrm{kg}^{-1}\right)$ & |------- & ------- & & ---------- & $\left(\mathrm{mg} \mathrm{kg}^{-1}\right)$ & ) -------- & & & 1 & 2 & 3 & & \\
\hline & \multicolumn{16}{|c|}{ Soybean } \\
\hline \multicolumn{17}{|l|}{ Year } \\
\hline $2008 / 2009$ & $44 *$ & $4.8^{*}$ & $29.8^{*}$ & $21.4 *$ & $6.7^{*}$ & $3.3 *$ & $16.4 *$ & $73 *$ & $132 *$ & $218 *$ & $4,222 *$ & $258^{*}$ & $38.0 *$ & $2.0^{*}$ & $18.0^{*}$ & $3,000^{*}$ \\
\hline $2009 / 2010$ & 43 & 4.6 & 24.9 & 20.6 & 6.1 & 2.3 & 12.0 & 69 & 123 & 178 & 3,412 & 218 & 37.9 & 2.9 & 15.4 & 3,277 \\
\hline \multicolumn{17}{|c|}{ F significance } \\
\hline Block & 0.101 & 0.656 & 0.206 & 0.644 & 0.053 & 0.443 & 0.4789 & 0.144 & 0.062 & 0.549 & 0.120 & 0.959 & 0.848 & 0.442 & 0.105 & 0.376 \\
\hline Lime (L) & $<0.001$ & 0.055 & 0.0079 & $<0.001$ & 0.002 & $<0.001$ & 0.0048 & $<0.001$ & $<0.001$ & 0.073 & $<0.001$ & 0.067 & $<0.001$ & 0.085 & $<0.001$ & $<0.001$ \\
\hline Year $(\mathrm{Y})$ & 0.098 & 0.021 & $<0.001$ & 0.028 & 0.001 & $<0.001$ & 0.0050 & 0.075 & 0.503 & 0.001 & $<0.001$ & $<0.001$ & 0.951 & $<0.001$ & $<0.001$ & $<0.001$ \\
\hline $\mathrm{L} \times \mathrm{Y}$ & 0.086 & 0.367 & 0.240 & 0.091 & 0.102 & 0.085 & 0.0905 & 0.109 & 0.992 & 0.111 & 0.220 & 0.389 & 0.510 & 0.085 & 0.067 & 0.086 \\
\hline & \multicolumn{16}{|c|}{ Black oat } \\
\hline \multicolumn{17}{|l|}{ Year } \\
\hline 2009 & 18.7 & 3.9 & 30.1 & 15.6 & 5.1 & 2.3 & 13.1 & 54 & 211 & 141 & 5,122 & 171 & 48 & 82 & 1.89 & 1,221 \\
\hline \multicolumn{17}{|c|}{ F significance } \\
\hline Block & 0.160 & 0.981 & 0.777 & 0.090 & 0.275 & 0.932 & 0.116 & 0.1952 & 0.104 & 0.999 & 0.984 & 0.985 & 0.122 & 0.119 & 0.838 & 0.991 \\
\hline Lime & 0.142 & 0.655 & 0.659 & $<0.001$ & $<0.001$ & 0.635 & 0.126 & 0.619 & $<0.001$ & 0.002 & $<0.001$ & $<0.001$ & 0.153 & 0.445 & 0.747 & $<0.001$ \\
\hline & \multicolumn{16}{|c|}{ Sorghum } \\
\hline \multicolumn{17}{|l|}{ Year } \\
\hline 2010 & 28.7 & 3.9 & 17.3 & 9.3 & 4.1 & 7.7 & 9.9 & 42 & 36 & 322 & 3547 & 14.8 & 183 & - & 3.57 & 1017 \\
\hline \multicolumn{17}{|c|}{ F significance } \\
\hline Block & 0.111 & 0.186 & 0.998 & 0.999 & 0.968 & 0.056 & 0.999 & 0.2414 & 0.980 & 0.9122 & 0.530 & 0.965 & 0.788 & - & 0.853 & 0.963 \\
\hline Lime & 0.004 & $<0.001$ & $<0.001$ & 0.001 & 0.063 & $<0.001$ & 0.220 & 0.1239 & 0.001 & 0.3574 & $<0.001$ & $<0.001$ & $<0.001$ & - & 0.144 & $<0.001$ \\
\hline
\end{tabular}

*Significant differences for year means, by the $\mathrm{t}$ test, at $5 \%$ probability. Yield component 1: population, for soybean; panicles per square meter, for black oat and sorghum. Yield component 2: pods per plant, for soybean; spikelets per panicle, for black oat; and grains per panicle, for sorghum. Yield component 3: grains per pod, for soybean; and spikelet fertility, for black oat. 
Surface lime application increased shoot dry matter yield of soybean, black oat, and sorghum, with the greatest values of lime estimated doses at 4,000, 2,333, and, 3,281 kg ha-1 (Table 3). These maximum values were near to those reported by other authors for soybean (Caires \& Fonseca, 2000), black oat (Soratto \& Crusciol, 2008d), and sorghum (Barbosa et al., 2008).

Liming increased soybean plant population and 100 -seed weight, with direct impact on grain yield (Table 3). The highest grain yield $\left(3,400 \mathrm{~kg} \mathrm{ha}^{-1}\right)-21 \%$ higher than that of the control plot - was achieved with $2,550 \mathrm{~kg}$ ha-1 estimated lime dose. For black oat, only the number of panicles per square meter was influenced by liming (Table 2), which had a quadratic effect (Table 3). This component positively impacted grain yield, with the highest yield $\left(1,480 \mathrm{~kg} \mathrm{ha}^{-1}\right)-61 \%$ higher than that of the control - obtained with 3,555 $\mathrm{kg} \mathrm{ha}^{-1}$ lime estimated dose.

Surface liming did not influence the 1,000-seed weight of sorghum (Table 2), but the number of panicles per square meter and grains per panicle of sorghum quadratically increased with liming (Table 3), which reflected on grain yield; however, the maximum productivity was not achieved with the studied doses. It is noteworthy that the low temperatures during the initial development of sorghum extended the vegetative period, and flowering occurred at a time of low water availability (mid-May 2010), which increased the flower sterility.

Table 3. Regression equations, and coefficients of determination, between different factors and lime rates.

\begin{tabular}{|c|c|c|c|c|c|c|}
\hline \multirow[t]{2}{*}{ Factor } & \multicolumn{4}{|c|}{ Lime rates $\left(\mathrm{kg} \mathrm{ha}^{-1}\right)$} & \multirow[t]{2}{*}{ Regression } & \multirow[t]{2}{*}{$\mathrm{R}^{2}$} \\
\hline & 0 & 1,000 & 2,000 & 4,000 & & \\
\hline & \multicolumn{4}{|c|}{ Soybean } & & \\
\hline $\mathrm{N}\left(\mathrm{g} \mathrm{kg}^{-1}\right)$ & 40.6 & 42.6 & 43.5 & 46.3 & $y=0.0014 x+40.875$ & 0.98 \\
\hline $\mathrm{K}\left(\mathrm{g} \mathrm{kg}^{-1}\right)$ & 28.1 & 28.0 & 27.6 & 25.7 & $y=-0.0006 x+28.455$ & 0.90 \\
\hline $\mathrm{Ca}\left(\mathrm{g} \mathrm{kg}^{-1}\right)$ & 17.9 & 21.1 & 22.0 & 22.9 & $y=-0.0000005 x^{2}+0.0031 x+18.045$ & 0.97 \\
\hline $\operatorname{Mg}\left(\mathrm{g} \mathrm{kg}^{-1}\right)$ & 6.0 & 6.5 & 6.8 & 6.3 & $y=-0.0000002 x^{2}+0.0007 x+5.9932$ & 0.99 \\
\hline $\mathrm{S}\left(\mathrm{g} \mathrm{kg}^{-1}\right)$ & 2.5 & 3.3 & 2.9 & 2.5 & $y=-0.0000001 x^{2}+0.0005 x+2.6023$ & 0.67 \\
\hline $\mathrm{Cu}\left(\mathrm{mg} \mathrm{kg}^{-1}\right)$ & 18.4 & 15.1 & 12.3 & 11.0 & $y=-0.0018 x+17.325$ & 0.87 \\
\hline $\mathrm{Zn}\left(\mathrm{mg} \mathrm{kg}^{-1}\right)$ & 93.8 & 71.6 & 67.1 & 51.1 & $y=0.000002 x^{2}-0.0181 x+92.117$ & 0.96 \\
\hline $\operatorname{Mn}\left(\mathrm{mg} \mathrm{kg}^{-1}\right)$ & 193.9 & 140.8 & 94.4 & 79.9 & $y=0.00001 x^{2}-0.0689 x+195.46$ & 0.99 \\
\hline Shoot dry matter $\left(\mathrm{kg} \mathrm{ha}^{-1}\right)$ & 3143 & 3873 & 4173 & 4078 & $y=-0,0001 x^{2}+0,8179 x+3,159.9$ & 0.99 \\
\hline Population (x1000 ha-1) & 222.0 & 247.0 & 251.0 & 232.0 & $y=-0.000006 x^{2}+0.0278 x+222.98$ & 0.97 \\
\hline Pods per pod & 35.1 & 37.4 & 37.3 & 42.1 & $y=0.0017 x+35.05$ & 0.92 \\
\hline 100-grain weight $(\mathrm{g})$ & 16.0 & 16.6 & 17.4 & 16.9 & $y=-0.0000002 x^{2}+0.0011 x+15.935$ & 0.95 \\
\hline \multirow[t]{2}{*}{ Grain yield $\left(\mathrm{kg} \mathrm{ha}^{-1}\right)$} & 2771 & 3350 & 3254 & 3181 & $y=-0.00009 x^{2}+0.459 x+2829$ & 0.78 \\
\hline & \multicolumn{4}{|c|}{ Black oat } & & \\
\hline $\mathrm{Ca}\left(\mathrm{g} \mathrm{kg}^{-1}\right)$ & 10.6 & 15.4 & 13.0 & 23.4 & $y=0.0029 x+10.454$ & 0.82 \\
\hline $\operatorname{Mg}\left(\mathrm{g} \mathrm{kg}^{-1}\right)$ & 4.6 & 4.9 & 5.4 & 5.4 & $y=-0.00000008 x^{2}+0.0005 x+4.5913$ & 0.92 \\
\hline $\operatorname{Mn}\left(\mathrm{mg} \mathrm{kg}^{-1}\right)$ & 258.8 & 242.4 & 195.0 & 150.1 & $y=-0.0284 x+261.23$ & 0.97 \\
\hline $\mathrm{Fe}\left(\mathrm{mg} \mathrm{kg}^{-1}\right)$ & 173.1 & 153.4 & 110.0 & 128.7 & $y=0.000008 x^{2}-0.0456 x+177.93$ & 0.88 \\
\hline Shoot dry matter $\left(\mathrm{kg} \mathrm{ha}^{-1}\right)$ & 4632 & 4897 & 5856 & 5103 & $y=-0.0002 x^{2}+0.9332 x+4502.5$ & 0.75 \\
\hline Panicles per square meter & 137.5 & 166.5 & 215.8 & 165.8 & $y=-0.00001 x^{2}+0.0636 x+131.79$ & 0.87 \\
\hline \multirow[t]{2}{*}{ Grain yield $\left(\mathrm{kg} \mathrm{ha}^{-1}\right)$} & 960 & 1113 & 1476 & 1339 & $y=-0.00006 x^{2}+0.3667 x+919.26$ & 0.87 \\
\hline & \multicolumn{4}{|c|}{ Sorghum } & & \\
\hline $\mathrm{N}\left(\mathrm{g} \mathrm{kg}^{-1}\right)$ & 27.2 & 28.3 & 28.8 & 30.7 & $y=0.0009 x+27.26$ & 0.98 \\
\hline $\mathrm{P}\left(\mathrm{g} \mathrm{kg}^{-1}\right)$ & 3.9 & 3.7 & 4.0 & 4.1 & $y=0.00007 x+3.8$ & 0.51 \\
\hline $\mathrm{K}\left(\mathrm{g} \mathrm{kg}^{-1}\right)$ & 18.0 & 18.4 & 17.9 & 15.2 & $y=-0.0008 x+18.7$ & 0.77 \\
\hline $\mathrm{Ca}\left(\mathrm{g} \mathrm{kg}^{-1}\right)$ & 9.4 & 10.7 & 11.2 & 11.8 & $y=0.0006 x+9.8$ & 0.87 \\
\hline $\mathrm{S}\left(\mathrm{g} \mathrm{kg}^{-1}\right)$ & 1.8 & 2.0 & 2.7 & 2.7 & $y=-0.00000008 x^{2}+0.0006 x+1.7209$ & 0.88 \\
\hline $\operatorname{Mn}\left(\mathrm{mg} \mathrm{kg}^{-1}\right)$ & 41.0 & 34.0 & 34.0 & 32.0 & $y=-0.0019 x+38.6$ & 0.69 \\
\hline Shoot dry matter $\left(\mathrm{kg} \mathrm{ha}^{-1}\right)$ & 1513 & 3788 & 4084 & 4804 & $y=-0.0003 x^{2}+1.9688 x+1678.4$ & 0.94 \\
\hline Panicles per square meter & 11.0 & 13.7 & 17.2 & 17.4 & $y=-0.0000006 x^{2}+0.0043 x+10.749$ & 0.98 \\
\hline Grains per panicle & 11.0 & 116.0 & 245.0 & 360.0 & $y=-0.00001 x^{2}+0.1389 x+5.1364$ & 0.99 \\
\hline Grain yield $\left(\mathrm{kg} \mathrm{ha}^{-1}\right)$ & 45 & 602 & 1452 & 1968 & $\mathrm{y}=-0.00009 \mathrm{x}^{2}+0.8512 \mathrm{x}-11.264$ & 0.98 \\
\hline
\end{tabular}


Grain yield showed the same pattern observed for yield components, with high correlations $(p<0.01)$ in soybean (100-seed weight, $\mathrm{r}=0.62$ ), black oat (panicles per square meter, $\mathrm{r}=0.91$ ), and sorghum (panicles per square meter, $\mathrm{r}=0.78$; and grains per panicle, $\mathrm{r}=0.98$ ) (Table 3). Similar results were observed by Sávio et al. (2011), for soybean, and Soratto \& Crusciol (2008d), for black oat.

It is noteworthy that grain production in the subtropical region does not always benefit from liming, particularly under water deficiency. This highlights the importance of the results reported here, in the tropical region, where liming always benefited grain production, even in years with regular rainfall distribution.

\section{Conclusions}

1. Surface liming is effective for reducing soil acidity and for increasing soil organic matter and $\mathrm{P}$, $\mathrm{Ca}^{+2}$, and $\mathrm{Mg}^{+2}$ contents on the subsurface.

2. Surface liming improves plant nutrition, especially of $\mathrm{N}, \mathrm{Ca}^{2+}$, and $\mathrm{Mg}^{2+}$; and it increases dry matter production and productivity of the evaluated crops, even in years with regular distribution of rainfall.

3. The reduction of limestone rates is not recommended, even in areas with great accumulation of soil organic matter.

\section{Acknowledgments}

To Fundação de Amparo à Pesquisa do Estado de São Paulo (Fapesp, registry number 2009/04126-3), for financial support, and to Conselho Nacional de Desenvolvimento Científico e Tecnológico (CNPq), for the research excellence award granted for the second author.

\section{References}

BARBOSA, N.C.; VENÂNCIO, R.; ASSIS, M.H.S.; PAIVA, J. de B.; CARNEIRO, M.A.C.; PEREIRA, H.S. Formas de aplicação de silicato de cálcio e magnésio na cultura do sorgo em Neossolo Quartzarênico de Cerrado. Pesquisa Agropecuária Tropical, v.38, p.290-296, 2008.

BRIEDIS, C.; SÁ, J.C. de M.; CAIRES, E.F.; NAVARRO, J. de F.; INAGAKI, T.M.; BOER, A.; QUADROS NETO, C.; FERREIRA, A. de O.; CANALLI, L.B.; SANTOS, J.B. dos. Soil organic matter pools and carbon-protection mechanisms in aggregate classes influenced by surface liming in a no-till system. Geoderma, v.170, p.80-88, 2012. DOI: 10.1016/j.geoderma.2011.10.011.
BRONICK, C.J.; LAL, R. Soil structure and management: a review. Geoderma, v.124, p.322, 2005. DOI: 10.1016/j. geoderma.2004.03.005.

CAIRES, E.F.; ALLEONI, L.R.F.; CAMBRI, M.A.; BARTH, G. Surface application of lime for crop grain production under a no-till system. Agronomy Journal, v.97, p.791-798, 2005. DOI: 10.2134/agronj2004.0207.

CAIRES, E.F.; BARTH, G.; GARBUIO, F.J. Lime application in the establishment of a no-till system for grain crop production in Southern Brazil. Soil and Tillage Research, v.89, p.3-12, 2006a. DOI: 10.1016/j.still.2005.06.006.

CAIRES, E.F.; BARTH, G.; GARBUIO, F.J.; CHURKA, S. Soil acidity, liming and soybean performance under no-till. Scientia Agricola, v.65, p.532-540, 2008a. DOI: 10.1590/S010390162008000500013.

CAIRES, E.F.; BARTH, G.; GARBUIO, F.J.; KUSMAN, M.T. Correção da acidez do solo, crescimento radicular e nutrição do milho de acordo com a calagem na superfície em sistema plantio direto. Revista Brasileira de Ciência do Solo, v.26, p.1011-1022, 2002. DOI: 10.1590/S0100-06832002000400019.

CAIRES, E.F.; CHURKA, S.; GARBUIO, F.J.; FERRARI, R.A.; MORGANO, M.A. Soybean yield and quality as a function of lime and gypsum applications. Scientia Agricola, v.63, p.370379, 2006b. DOI: 10.1590/S0103-90162006000400008.

CAIRES, E.F.; CORRÊA, J.C.L.; CHURKA, S.; BARTH, G.; GARBUIO, F.J. Surface application of lime ameliorates subsoil acidity and improves root growth and yield of wheat in an acid soil under no-till system. Scientia Agricola, v.63, p.502-509, 2006 c. DOI: $10.1590 / \mathrm{S} 0103-90162006000500013$.

CAIRES, E.F.; FONSECA, A.F. da. Absorção de nutrientes pela soja cultivada no sistema de plantio direto em função da calagem na superfície. Bragantia, v.59, p.213-220, 2000. DOI: 10.1590/ S0006-87052000000200013.

CAIRES, E.F.; FONSECA, A.F.; MENDES, J.; CHUEIRI, W.A.; MADRUGA, E.F. Produção de milho, trigo e soja em função das alterações das características químicas do solo pela aplicação de calcário e gesso na superfície, em sistema plantio direto. Revista Brasileira de Ciência do Solo, v.23, p.315-327, 1999. DOI: 10.1590/S0100-06831999000200016.

CAIRES, E.F.; GARBUIO, F.J.; ALLEONI, L.R.F.; CAMBRI, M.A. Calagem superficial e cobertura de aveia preta antecedendo os cultivos de milho e soja em sistema plantio direto. Revista Brasileira de Ciência do Solo, v.30, p.87-98, 2006d. DOI: 10.1590/S0100-06832006000100010.

CAIRES, E.F.; GARBUIO, F.J.; CHURKA, S.; BARTH, G.; CORREAA, J.C.L. Effects of soil acidity amelioration by surface liming on no-till corn, soybean, and wheat root growth and yield. European Journal of Agronomy, v.28, p.57-64, 2008b. DOI: 10.1016/j.eja.2007.05.002.

CAIRES, E.F.; JORIS, H.A.W.; CHURKA, S. Long-term effects of lime and gypsum additions on no-till corn and soybean yield and soil chemical properties in Southern Brazil. Soil Use and Management, v.27, p.45-53, 2011. DOI: 10.1111/j.14752743.2010.00310.x. 
CAIRES, E.F.; PEREIRA FILHO, P.R.S.; ZARDO FILHO, R.; FELDHAUS, I.C. Soil acidity and aluminium toxicity as affected by surface liming and cover oat residues under a no-till system. Soil Use and Management, v.24, p.302-309, 2008c. DOI: 10.1111/j.1475-2743.2008.00166.x.

CASTRO, G.S.A.; CRUSCIOL, C.A.C. Effects of superficial liming and silicate application on soil fertility and crop yield under rotation. Geoderma, v.195/196, p.234-242, 2013a. DOI: 10.1016/j.geoderma.2012.12.006.

CASTRO, G.S.A.; CRUSCIOL, C.A.C. Yield and mineral nutrition of soybean, maize, and Congo signal grass as affected by limestone and slag. Pesquisa Agropecuaria Brasileira, v.48, p.673-681, 2013b. DOI: 10.1590/S0100-204X2013000600013.

CIOTTA, M.N.; BAYER, C.; ERNANI, P.R.; FONTOURA, S.M.V; ALBUQUERQUE, J.A.; WOBETO, C. Acidificação de um latossolo sob plantio direto. Revista Brasileira de Ciência do Solo, v.26, p.1055-1064, 2002. DOI: 10.1590/S010006832002000400023.

CORRÊA, J.C.; BULL, L.T.; CRUSCIOL, C.A.C.; MORAES, M.H. Alteração de atributos físicos em Latossolo com aplicação superficial de escória de aciaria, lama cal, lodos de esgoto e calcário. Revista Brasileira de Ciência do Solo, v.33, p.263272, 2009. DOI: 10.1590/S0100-06832009000200004.

ERNANI, P.R.; RIBEIRO, M.F.S.; BAYER, C. Chemical modifications caused by liming below the limed layer in a predominantly variable charge acid soil. Communications in Soil Science and Plant Analysis, v.35, p.889-901, 2004. DOI: 10.1081/CSS-120030365.

FRANCHINI, J.C.; HOFFMANN-CAMPO, C.B.; TORRES, E.; MIYAZAWA, M.; PAVAN, M.A. Organic composition of green manure during growth and its effect on cation mobilization in an acid oxisol. Communications in Soil Science and Plant Analysis, v. -34, p.2045-2058, 2003. DOI: 10.1081/CSS120023237.

ISLAM, A.; WHITE, R.E.; CHEN, D. Nitrification activity in acid soils of north-eastern Victoria, Australia, as affected by liming and phosphorus fertilisation. Australian Journal of Soil Research, v.44, p.739-744, 2006. DOI: 10.1071/SR06058.

MALAVOLTA, E.; VITTI, G.C.; OLIVEIRA, S.A. de. Avaliação do estado nutricional das plantas: princípios e aplicações. 2.ed. Piracicaba: Potafos, 1997.

MIYAZAWA, M.; PAVAN, M.A.; FRANCHINI, J.C. Evaluation of plant residues on the mobility of surface applied lime. Brazilian Archives of Biology and Technology, v.45, p.251256, 2002. DOI: 10.1590/S1516-89132002000300001.

NOLLA, A.; ANGHINONI, I. Atividade e especiação química na solução afetadas pela adição de fósforo em latossolo sob plantio direto em diferentes condições de acidez. Revista Brasileira de Ciência do Solo, v.30, p.955-963, 2006. DOI: 10.1590/S010006832006000600005.

OLIVEIRA, E.L. de; PAVAN, M.A. Control of soil acidity in no-tillage system for soybean production. Soil and
Tillage Research, v.38, p. 47-57, 1996. DOI: 10.1016/01671987(96)01021-5.

PAVAN, M.A.; ROTH, C.H. Effect of lime and gypsum on chemical composition of runoff and leachate from samples of a Brazilian Oxisol. Ciência e Cultura, v.44, p.391-394, 1992.

RAIJ, B. van; CANTARELLA, H.; QUAGGIO, J.A.; FURLANI, A.M.C. Recomendações de adubação e calagem para o Estado de São Paulo. 2.ed. rev. e atual. Campinas: IAC, 1997. 285p. (Boletim técnico, 100).

RHEINHEIMER, D.S.; SANTOS, E.J.S.; KAMINSKI, J.; BORTOLUZZI, E.C.; GATIBONI, L.C. Alterações de atributos do solo pela calagem superficial e incorporada a partir de pastagem natural. Revista Brasileira de Ciência do Solo, v.24, p.797-805, 2000. DOI: 10.1590/S0100-06832000000400012.

SÁVIO, F.L.; SILVA, G.C. da; TEIXEIRA, I.R.; MOTA, J.H.; BORÉM, A. Calagem e gessagem na nutrição e produção de soja em solo com pastagem degradada. Revista Agrotecnologia, v.2, p. 19-31, 2011. DOI: 10.12971/2179-5959.v02n01a02.

SORATTO, R.P.; CRUSCIOL, C.A.C. Atributos químicos do solo decorrentes da aplicação em superfície de calcário e gesso em sistema plantio direto recém-implantado. Revista Brasileira de Ciência do Solo, v.32, p.675-688, 2008a. DOI: 10.1590/S010006832008000200022 .

SORATTO, R.P.; CRUSCIOL, C.A.C. Dolomite and phosphogypsum surface application effects on annual crops nutrition and yield. Agronomy Journal, v.100, p.261-270, 2008 b. DOI: 10.2134/agrojn12007.0120.

SORATTO, R.P.; CRUSCIOL, C.A.C. Nutrição e produtividade de grãos da aveia-preta em função da aplicação de calcário e gesso em superfície na implantação do sistema plantio direto. Revista Brasileira de Ciência do Solo, v.32, p.715-725, 2008c. DOI: 10.1590/S0100-06832008000200026.

SORATTO, R.P.; CRUSCIOL, C.A.C. Produção de fitomassa e acúmulo de nutrientes pela aveia-preta em função da aplicação de calcário e gesso em superfície na implantação do sistema plantio direto. Ciência Rural, v.38, p.928-935, 2008d. DOI: 10.1590/ S0103-84782008000400004.

SOUZA, R.F. de; FAQUIN, V.; TORRES, P.R.F.; BALIZA, D.P. Calagem e adubação orgânica: influência na adsorção de fósforo em solos. Revista Brasileira de Ciência do Solo, v.30, p.975-983, 2006. DOI: 10.1590/s0100-06832006000600007.

VIEIRA, F.C.B.; BAYER, C.; ZANATTA, J.; ERNANI, P.R. Organic matter kept Al toxicity low in a subtropical no-tillage soil under long-term (21-year) legume-based crop systems and $\mathrm{N}$ fertilisation. Australian Journal of Soil Research, v.47, p.707714, 2009. DOI: 10.1071/SR08273.

WATT, H.V.H. van der; BARNARD, R.O.; CRONJE, I.J.; DEKKER, J.; CROFT, G.J.B.; WALT, M. M. van der. Amelioration of subsoil acidity by application of a coal-derived calcium fulvate to the soil surface. Nature, v.350, p.146-148, 1991. DOI: $10.1038 / 350146 \mathrm{a} 0$.

Received on August 20, 2015 and accepted on June 21, 2016

Pesq. agropec. bras., Brasília, v.51, n.9, p.1633-1642, set. 2016

DOI: $10.1590 / \mathrm{S} 0100-204 X 2016000900063$ 